\title{
ДИЈАЛЕКАТСКА ЈЕЗИЧКА СЛИКА СВЕТА КАО ЛИНГВОКУЛТУРОЛОШКИ ФЕНОМЕН**
}

Савремена словенска дијалектологија усмерена је на расветљавање феномена дијалекатске језичке слике света као територијално ограниченог сегмента националне језичке слике света. Актуелна истраживања у овој области науке о језику, посебно у русистици, дају значајне резултате у реконструисању модела концептуализације и категоризације објективне стварности у свести носилаца народних говора и њиховој језичкој интерпретацији и репрезентацији. Комбиновање модерних теорија и методолошких механизама, пре свега лингвокогнитивистичких и лингвокултуролошких, показало се као адекватан поступак у анализи дијалекатског материјала. Дијалекатска лексика сагледава се као одраз погледа на свет и менталитета дијалекатске језичке личности, а дијалекатски речници постају најрелевантнији извори за проучавање лингвокултурних специфичности конкретне говорне заједнице. Наш циљ је оријентисан на приказ модела концептуализације стварности дијалекатске језичке личности и вербалну манифестацију одређених културних / аксиолошких концепата на дијалекатској језичкој слици света српског језика, с обзиром на чињеницу да се дијалекти одликују богатим културолошким потенцијалом, чије проучавање са становишта лингвокултурологије шири могућности језичких истраживања. У раду ћемо представити реализацију концепта (не)хигијене у језичком сазнању носилаца призренско-тимочких говора, његову когнитивну интерпретацију и вербалну манифестацију на призренско-тимочкој дијалекатској слици света и покушати да издвојимо специфичне лингвокултурне елементе који одсликавају карактеристике менталитета и погледа на свет ове говорне заједнице.

Кључне речи: дијалекатска лингвокултурологија, призренско-тимочка језичка слика света, концепт (не)хигијине.

Премиса „човек у језику и језик у човеку” основни је постулат актуелне лингвистичке парадигме - антропоцентризма. Правци у савременој лингвистици настали у оквирима антропоцентричке парадигме су когнитивна

*tanja77nis@gmail.com

** Овај рад финансирало је Министарство просвете, науке и технолошког развоја Републике Србије према Уговору број 451-0368/2020-14/200174 који је склопљен са Институтом за српски језик САНУ. 
лингвистика и лингвокултурологија. О укрштању ове две дисциплине пише Р. Драгићевић, указујући на њихове заједничке елементе и дистинктивна обележја која их чине самосталним лингвистичким правцима (в. Драгићевић 2015). Когнитивна лингвистика истражује принципе организације људског сазнања, моделе категоризације и концептуализације објективне стварности у човековој свести, формирање концепата као менталних конструкта и њихову вербалну манифестацију, тежећи разоткривању универзалних елемената са фокусом на појам прототипа. Из когнитивистике се крајем 20. века изродила лингвокулторологија, дефинисана као „научна дисциплина настала прожимањем лингвистике и културологије која се бави истраживањем појава националне културе одражених у језику” (Маслова 2001: 27). Лингвокултурологија проучава поглед на свет кроз призму националног језика, при чему се језик сагледава као израз особеног националног менталитета, као феномен националне културе. Примарно је оријентисана је на „културни фактор у језику и на језички фактор у човеку” (В. Н. Телија, према Маслова 2001: 8), полазећи од становишта да је материјална и духовна култура народа инкорпорирана у национални језик и да се испољава у језичким појавама и процесима, са циљем да разоткрије културно маркиране јединице као носиоце националне специфичности и испита начине на које језик акумулира, чува и преноси културне информације. Најпоузданији начин детектовања лингвокултурема јесте реконструисање лингвокултурних концепата на језичкој слици света. Са лингвокултуролошког аспекта језичка слика света је поглед на свет припадника одређене културе одражен у језику, систем вредносних оријентација кодиран у асоцијативним компонентама језичких јединица (Демидова 2012: 181). Анализа националне језичке слике света има важну улогу у истраживању поимања стварности конкретне језичке личности / етноса, с обзиром на то да представља процесе и резултат одраза историјског, културног, социјалног и језичког искуства одређене етничке / језичке / културне заједнице. При томе не треба губити из вида да особености било којег националног језика не творе посебну и самосталну слику света, већ појавама из реалног окружења дају специфичну нијансу која је условљена значајем реалија у свакодневном животу, мишљењу и националној култури народа (Шуригина 2014: 187).

Последњу деценију, у радовима Р. Драгићевић, лексика савременог српског језика и српска фразеологија све се више посматрају из угла савремених теорија и почињу интензивно да се проучавају методама лингвокогнитивистике и лингвокултурологије. У средишту пажње истраживача су језичка слика света, језичка личност и концепт. Српска наука о језику богати се методолошки иновативним радовима у којима се анализирају универзални и национално маркирани концепти у српском језику (Р. Драгићевић, С. Ристић, Д. Мршевић Радовић, Г. Штрбац, Н. Вуловић, И. Лазић Коњик, С. Новокмет, В. Николић и др.). Веза између језика и културе у српској лингвистици испитује се углавном на грађи из речника савременог српског језика и на материјалу прикупљеном асоцијативном методом. Наше интересовање усмерено је на народне говоре и у складу са тим циљ овога рада оријентисан је на 
приказ модела концептуализације стварности дијалекатске језичке личности и вербалну манифестацију одређених културних / аксиолошких концепата на дијалекатској језичкој слици света српског језика.

Ако је лингвокултурологија схваћена као веза два знаковна система, језика и културе, дијалекатска лингвокултурологија је њен део повезан са односом народног говора и традиционалне културе, тј. локалних идиома и локалних култура. Еквивалентно тријади језик - нација - култура, која је у основи лингвокултурологије, дијалекатска лингвокултуролошка испитивања почивају на вези народни говор / дијалекат - дијалекатска заједница - традиционална култура. Савремена словенска дијалектологија усмерена је на расветљавање феномена дијалекатске језичке слике света као територијално ограниченог сегмента националне језичке слике света. Актуелна истраживања у овој области науке о језику, посебно у русистици, дају значајне резултате у реконструисању модела концептуализације и категоризације објективне стварности у виду концепата и њиховој језичкој интерпретацији и репрезентацији. Дијалекатска лексика сагледава се као одраз погледа на свет и менталитета дијалекатске језичке личности, а дијалекатски речници постају најрелевантнији извори за проучавање лингвокултурних специфичности конкретне говорне заједнице. Лингвокултуролошки приступ дијалекатском лексичком систему омогућује екстраховање културних компонената у семантичком садржају језичких јединица у којима су акумулиране информације о начину мишљења, живота и традиционалној култури колектива. Дијалекатска језичка слика света (ДЈСС) чува уникатне црте погледа на свет конкретне дијалекатске језичке личности, које су детерминисане елементима културе говорне заједнице (субетноса) и модел њихове вербализације на конкретној територији функционисања језика (Демидова 2015: 48). Анализа особености погледа на свет дијалекатске заједнице на основу дијалекатске лексике омогућује да се увиди шта дијалекатски колектив издваја, како и зашто бира одређена језичка средства за номинацију концепата концептосфере која га окружује, тј. који ментални и културни фактори условљавају регионалне особености језичке концептуализације и категоризације објективне стварности (Демидова 2011: 8). Дијалекатску заједницу карактерише и осећајни и емоционални тип поимања стварности, с обзиром на мишљење дијалекатске личности засновано на емпирији, што се очитава у конотативној значењској равни лексичких јединица и у великој мери одражава вредносни систем говорне заједнице.

Као илустрацију наведених тврдњи представићемо реализацију концепта (не)хигијене у језичкој свести носилаца југоисточних српских говора и његову манифестацију на призренско-тимочкој језичкој слици света. Овај аксиолошко-културни концепт одабрали смо због значаја који има у вредносном систему и култури призренско-тимочке језичке личности који се очитава на дијалекатској језичкој слици света, а огледа се у слојевитости семантичког садржаја и сложеној парадигматској организацији концепта, с обзиром на чињеницу да различитим зонама (језгреном, централном, периферном) задире у различите домене објективне стварности и из више углова осветљава 
слику централног објекта језичке стварности - човека. Појам хигијене когнитивно се везује за разне аспекте човекове личности, јер обухвата широк дијапазон људских својстава који директно или индиректно детерминишу човеков однос према личној хигијени (од психо-моторних (ментална и физичка способност), естетских, карактерних, до оних који су условљени социјалним и културним факторима). Изванјезички елементи у великој мери утичу на вербалну интерпретацију овога концепта и одређују распоред јединица у оквиру лексичко-семантичке парадигме, обликујући структуру концепта. Лингвокултурне ознаке концепта у језичком сазнању призренско-тимочке дијалекатске личности испитујемо на грађи из Антропографског речника југоисточне Србије (Богдановић 2016) и Збирке речи из Призрена Димитрија Чемерикића.

Иако концепт (не)хигијене није експлицитно маркиран као културни концепт, његови језички репрезенти одражавају елементе традиционалне духовне културе у оном сегменту стварности који је асоцијативно повезан са здрављем и лепотом као основним вредностима како у општем тако и у усколокалном поимању света и живота. Културна обележја концепта испољавају се на конотативном плану значења, у експресивном језичком изразу. Дијалекатска лексика одликује се високим степеном експресивности с обзиром на изражајност, сликовитост, афективност, неформалност језичког израза дијалекатске личности, посебно у домену карактеризације личности по негативној особини. Укупна статистика негативних вербалних репрезентација макроконцепта човек у говорима југоисточне Србије предочава језичку чињеницу да се међу првих десет најбројнијих синонимских редова котирају микроредови са интегралним идентификационим семантичким обележјем 'неуредан' (са 168 ознака у Антропографском речнику и 25 јединица у Чемерикићевом лексикону). Оваква ситуација у асоцијативном пољу човек на призренско-тимочкој језичкој слици света стимулативна је за детаљнију когнитивно-семантичку и лингвокултуролошку анализу дијалекатске лексике са хиперсемом 'неуредна особа'.

Уредност / неуредност двоструко се перципирају на нивоу карактеризације личности: као спољашња одлика човека - ефекат који се чулно региструје и констатује и као унутрашња (психичка) карактеристика - немарљивост, лењост, слабост духа. У пресеку те две когнитивно-мотивационе равни конструисана је негативна семантичка зона концепта базирана на укрштању два модела: 'особа + спољашња особина' и 'особа + унутрашња особина', попуњена експресивима. Прототипична, неутрална вредност у естетском сазнању призренско-тимочке дијалекатске личности јесте појам уредности, педантности. Однос према хигијени културно је кодиран, тако да свака врста претеривања подлеже строгој критици колектива, што се очитава у организацији елемената концепта.

Позитивном пољу припадају јединице које репрезентују стереотип уредног човека - мазан, ч'ел'ебија (тур. çelebi), односно жене коко́на, и'ил'uмо́нда и ч'икл'имо́на (примери из призренског говора). У семантичком језгру ових номинација налазе се идентификационе компоненте 'господин', однос- 
но 'госпођа', што упућује на модел концептуализације хигијене као својства градског становништва и то виших слојева грађанства и поима се као норматив лепог, пристојног и уредног спољашњег изгледа. Уколико прелази границе естетског формиране у свести колектива, особа је изложена подсмеху, ругању и вербалном етикетирању. Тако су се на оси негативне номинације

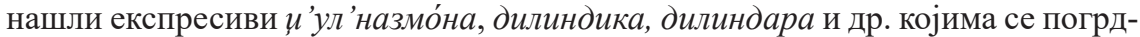
но означава „особа која се дотерује, кити, кинђури” и приписује се и мушкарцима и женама.

Негативно поље концепта далеко је обимније и садржајније. Дескриптивно-аксиолошко значење 'неуредан' интегрални је семантички знак који повезује јединице којима се означавају особине или носиоци особина вредновани естетским и етичким принципима заснованим на објективној оцени 'лоше' уграђеним у естетски и етички кодекс носилаца дијалекта. Опште семантичко обележје 'неуредан - који не одржава личну хигијену' раслојава се диференцијалним концептуалним знацима рангирајући распоред елемената у структури концепта. Бројност језичких ознака за вербализацију значењских сегмената концепта основни је параметар у реконструкцији концепта нехигијене, која се у призренско-тимочком сазнању концептуализује као неуредност.

У средишту концепта груписани су експресиви који реализују допунску компоненту 'неуредан у одевању', која обједињује редундантне семе '(онај) који је у неуредној, поцепаној, подераној, прљавој одећи или обући': влачопети́в, дрпав, дри́шав, дри́шљав, дро́ндав, дро́њав, дро́юес, дро́nљав, дропљи́в, др́тав, жва́кав, жму́кав, засмакља́вен, ка́страв, па́риав, сма́кљав, смакљо́сан, смандро́сан, сопа́сан, чо́лпав, чо́лтав, чо́рљав, иља́мпав, штро́кав; влачопети́на, влачопето́ња, Га́бел', дри́паи, дри́пља, дри́пша, дри́шља, дро́љча, дро́љша, дро́ња, дро́юча, дро́пча, дрпа́к, жва́кља, надрагузи́на, надрамо́љ, неперо́тина, неперчи́на, парама́нко, пр́чља, развлечо́тина, разлепа́нко, распара́нда, распара́нга, сарама́нда, чо́лта, чолта́н, сма́кља, смакља́вко, смакља́н, смакљо́ч, смакноти́на, има́кља, шмо́кља, шмокља́н; Габе́л'ка, дри́пла, др́љка, дрл'авйца, др́љна, дрља́ча, др́нда, дро́ља, дро́пла, дро́nља, дро́nна, др́пла, др́пна, жва́кна, ска́пла, сма́кла, смакља́вка, смакља́на, смакно́тина, цр́вла, чолта́на, шмо́кла, шмокља́на, шмокља́нка.

Централну зону концепта попуњавају именовања са идентификационом компонентом 'неуредан у изгледу', чији језгрени садржај „који не одржава личну хигијену" допуњују квалификаторима 'запуштен / прљав / нечист / неумивен, неопран': гала́тан, галатљи́в, е́л'ач', жму́кав, ка́страв, мр́шкав, му́сес, мьикав, неаљи́в, не́мит, гло́тан, о́љав, о́р, о́ран, пр́чав, уа́чкан; алоса́ник, а́јдук, биво́лар, ва́мпир, ве́штер, вьшл'а́вац, де́рвиш, дрл'а́вац, дрл'а́вко, гло́т, гло́теш, гло́тник, др́љко, дрља́н, др́љча, заразо́тина заразо́тљак, љо́nча, љо́nа, љо́пша, ме́ч'кар, мрља́н, мр́љча, мршко́љ, му́соња, смр́дља, смра́дља, ци́броња, иљь́́пча, шљи́пча, штрокља́н, чттро́кча; алосани́иа, арамза́да, бивол 'и́ца, буниу́ла, вьил'ави́ца, глотни́цุа, глоте́шка, ђубришта́рка, замазо́тина, заразо́тина, каљавшти́на, љо́пна, мр́љна, мурда́рка, мурда- 
ру́ша, неперо́тина, пепел'у́ша, смр́дла, смра́дла, смрдљи́вка, смрдљу́га, смр́дна, итрокави́ца, шттрокавшти́на, итро́кла, штро́кна.

Концептуализација нехигијене у призренско-тимочким говорима обухвата и оне спољашње ефекте који изазивају емоционалну реакцију околине и провоцирају вербалну креативност говорника, а посебно су упечатљиве чупавост, слинавост и рохавост као периферни стимулуси лексикализације основног појма. Са неуредношћу асоцира дуга, запуштена, неочешљана, разбарушена коса: бућогла́вес, гргу́рав, гр́чав, гр́кав, дурмес, ђу́мес, коса́т, косма́m, космура́m, котруљи́в, ку́драв, ску́бав, смькља́в, тр́шав, тр́шљав, чу́мав, чу́млав, чупе́с, рашчу́мен; бућогла́вко, битллез, грбуља́н, гр́чла, Ђу́мча, коса́р, космура́н, косура́н, ко́травац, котруља́н, нестри́жљьа, сколуба́н, ску́бља, трша́н, тр́шља, тршља́вко, ћуба́н, чуми́ло, чу́мља, чу́пља; бућогла́вка, гргуља́на, Ђуђума́ча, Ђу́ма, Ђу́мка, Ђу́мна, космура́на, котра́вка, котруља́ча, кудрави́ца, скуба́ра, ску́бла, ску́бна, скубољи́на, скубу́ља, тршља́вка, ћуба́нка, чума́ва, чумави́uฺ, чума́ра, чупави́ца, чýnна, иумája. Фрагмент слинаве особе уклапа се у стереотип о спољашњој неуредности и изазива интензивну емоционалну реакцију говорника вербализовану експресивима: гми́рчав, љи́гав, мрсољи́в, сомура́с, цивкаи́в, циинкав, ции́нћав, ции́ькав, sи́вав, súнsав, súнцав, имркутьви́в; ба́лча, љига́вко, љига́н, љи́гча, љиго́ша, љи́гша, мрсољи́вко, мрсо́љко, мрсол'а́вко мрсола́вац, сомура́н, сомура́нко, сому́рко, сомурља́вко, сомурља́н, сому́рча, сопуља́н, усмрко́ја, усмриа́н, ичико́в, ичивка́н, цивка́на, цимбо́њь, ции́ња, sива́н, sи́вља, sинго́в, sинsа́вко, sи́ниа, шмр́кља, шмркља́н, шмркоља́к, шмркутљи́вко; љига́вка, љи́гна, мрсољиви́йа, мрсол'а́вка, сомура́на, сомура́нка, сомурља́вка, сомурља́на, сомура́ча, сопуља́на, сопуља́нка, усмрко́јла, усмрку́ља, усмрку́ша, sива́ча, sина́́вка, шмркла. Концепт неуредног човека на периферији укључује и рохаву (бубуљичаву) особу са солидном лексичком интерпретацијом на дијалекатској језичкој слици света: бубуља́в, бубуља́с, вр́гав, гу́кав, жь́мбав, квр́гав, ко́чав, ко́чкав, кра́став, лу́нћав, лу́ьав, нажьмбав, пр́шав, ро́шав, ушьа́мен, шантав, ша́нтив, шантиња́в, ша́ргав, шко́бав, шо́ндрав; а́браш, белодроби́на, бубуља́н, вр́гља, вр́кча, гу́кша, кочи́л, ко́чко, луњавчи́на, луњавшти́на, луња́р, ро́ша, рошіавко, ро́шча, шко́бља; бубуља́на, бубуља́ча, вр́гна, ко́чка, краста́ча, луња́рка, роша́вка, ро́шка, ро́шла.

На крајњој периферији концепта орбитирају јединице са дистинктивним семантичким знаком 'неуредан у послу': ájmaв, ајто́сан, áљав; аљка́вко, аљьвити́на, аљто́в, а́љча, му́рда; аљави́йа, а́љка, аљка́вка, удаљавајући се од примарног значења концепта нехигијене који се односи на неуредан спољашњи изглед човека, одржавајући појам неуредности који продире у сферу човековог односа према раду. У основи номинација налази се придев аљкав, односно ајтав, колоквијално веома искоришћен, који у конкретним говорним ситуацијама актуелизује неку од имплицитних сема 'неуредан у понашању', 'неуредан у завршавању обавеза', 'неуредан у обављању радних задатака' и сл.

Највиши степен експресивности остварује се семантичком трансформацијом јединица, при чему метафоре настале варирањем једног семантичког знака полазног садржаја, одражавају стереотипе носилаца дијалекта о 
изворима нечистоће и прљавштине и уврежено мишљење о представницима „прљавих” занимања. У Призрену су прототипични носиоци ове особине хајдуци, дервиши, мечкари, биволари, па се ови називи приписују особама које изгледају запуштено, неуредно, одрпано, прљаво. Прототипично је асоцијативно поређење са апстрактним вредностима из појмовног домена народног веровања за изражавање субјективног односа према појави са наглашеном афектизацијом: вампир, вештер. Етнички стереотип о Ромима као народу који не води рачуна о личној хигијени огледа се у номинацијама из призренског српског говора Габел', Габел'ка. За постизање повишеног степена експресивности, поред оних који су познати на ширем дијалекатском подручју (-ина, -етина, -ана, -оља) призренско-тимочка дијалекатска личност употребљава пејоративне форманте који у комбинацији са пејоративном дијалекатском основом дају карактеристичне облике за ову област: -s $a$, -иа, -ча, -ољ за мушке особе (дрипља, жвакља, дришљь, дрипиа, дрољиа дрољча, дроњча, дропча, мршкољ), односно за женске -на, -ла, -ља (дропна, дрпна, жвакна, љигна, скапла, смакла, смрадла, дропља). Афективна тоналност ублажава се употребом деминутивно-хипокористичног суфикса -ко у реализацији са пејоративном основом, што је још једна језичка особеност ових говора: смакљавко, парама́нко, дрл 'а́вко, дрљко, мрсол'а́вко...

Експресивна вербална репрезентација концепта нехигијене на призренско-тимочкој језичкој слици света сведочи о високо развијеној свести носилаца југоисточних српских говора у вези са значајем одржавања личне хигијене и уредне спољашњости. У свести носилаца говора неуредност се непосредно доводи у везу са одрпаном, неопраном одећом, изгледом који изазива гађење, непријатним мирисом, сврабом, краставошћу. На следећем когнитивном нивоу асоцира са лењошћу, затим са непристојним изражавањем и на крају са ометеним менталним развојем. Потврду за модел концептуализације нехигијене, као одраза негативних унутрашњих својстава личности, налазимо у самој семантичкој структури већине лексичких јединица, где је једно од значења, поред „неуредан” управо ,лењ” (аљкавица „неуредна жена; нерадница) или „брбљив, непристојан у говору” (мурдар) и даље „ментално заостао". Занимљиво је да концепт хигијене у језичком сазнању представника призренско-тимочког дијалекта не експлицира директну изванјезичку каузалност хигијене и здравља, тј. нехигијене и болести, што је универзална одлика концепта. Брига о спољашњем изгледу, према схватању носилаца јужних и источних српских говора, корелира са менталним и карактерним склопом личности; чистоћа лица, тела, одеће еквивалентна је бистрини ума и чистоти духа и маркантна је особина оба пола. Концептуализација хигијене тела као одраза менталне хигијене, вербална интерпретација односа дијалекатске личности према овом сегменту објективне стварности и дијалекатски обојена експресивна вербална манифестација на језичкој слици света носиоци су лингвокултурног спецификума у којем је рефлектован менталитет и поглед на свет ове говорне заједнице. На основу језичке репрезентације и интерпретације концепта (не)хигијене на призренско-тимочкој језичкој слици света може се реконструисати однос говорника према овом сегменту 
стварности, који је као одраз обичајне праксе и свакодневног начина живота социјално и културно детерминисан и као такав испоставља се као важна компонента културног идентитета становништва југоисточне Србије.

Лексичко-семантичка и когнитивно-семантичка анализа антропографске лексике призренско-тимочких говора, потврдила је аксиом који важи за словенске језике и дијалекте, одражавајући притом локални лингвокултурни спецификум. Модел концептуализације стварности дијалекатске личности има прагматички карактер, јер начин живота детерминише доживљај и спознају стварности и самим тим одређује шта се у перцептивно-сазнајном процесу испоставља као важно и доминантно за дијалекатску језичку личност и које ознаке концепта играју улогу у номинационом процесу. Говорна заједница перципира типичне психичке или физичке црте као доминантна својства личности, и, процењујући их у односу на прототип, креира лексичку ознаку у чији садржај уноси свој вредносни суд. Стога, језичке јединице овога типа садрже субјективно-аксиолошке значењске елементе који рефлектују одлике менталитета говорне заједнице. Семантичке карактеристике многочланих синонимских редова садрже негативне асоцијације, на основу којих се могу реконструисати вредносни и културни оријентири колектива, јер је асоцијативна веза умногоме одређена условима живота и културом социјума. Дешифрујући кодове традиционалне културе преко експресивно маркиране лексике, аксиолошки метод проучавања ДЈСС открива потенцијал дијалекатске лексике за испитивање карактера културне информације и модела чувања и преношења вредносне информације у конкретном народном говору. С обзиром на чињеницу да се дијалекти одликују богатим културолошким потенцијалом, проучавање са становишта лингвокултурологије шири могућности језичких истраживања народних говора и доприноси развоју наше дијалекатске лексикологије. Посматрање дијалекатске језичке слике света као лингвокултуролошког феномена отвара врата новој дисциплини у нашој науци о језику - дијалекатској лингвокултурологији.

\section{ИЗВОРИ}

Богдановић 2016: Н. Богдановић, Антропографски речник југоисточне Сpбије, СДЗб, 58. Београд: Институт за српски језик САНУ, 3-275.

Чемерикић: Д. Чемерикић, Збирка речи из Призрена. < http://www.prepis.org/>

\section{ЛИТЕРАТУРА}

Демидова 2011: К. И. Демидова, Диалектная лексика как источник изучения диалектной языковой картины мира, Вестник Южно-уральского государственного университета. Серия: лингвистика, № 22, 6-9. <https:// cyberleninka.ru/article/n/dialektnaya-leksika-kak-istochnik-izucheniya- 
dialektnoy-yazykovoy-kartiny-mira-v-psiholingvisticheskom-aspekte/ viewer> 10. 3. 2020.

Демидова 2012: К. И. Демидова, „Словарь лексики говоров среднего Урала” как лингвокультурологический источник, Политическая лингвистика, Вып. 1(39). <http://www.philology.ru/linguistics2/demidova-12.htm> 18. 3. 2020

Демидова 2015: К. И. Демидова, Языковая картина мира в региональном аспекте, Педагогическое образование в России, № 12.<file://C:/Users/ pc2012/Downloads/yaz-kovaya-kartina-mira-v-regionalnom-aspektenauchnaya-shkola-doktora-filologicheskih-nauk-professora-k-i-demidovoy. pdf $>18$. 3. 2020 .

Драгићевић 2015: Р. Драгићевић, Укрштање когнитивне лингвистике и лингвокултурологије, Speech And Language. <http://www.iefpg.org. rs/Conference/2015/SL2015/2015_PROCEEDINGS_SPEECH_AND_ LANGUAGE_2015.pdf > 20.4.2020.

Маслова 2001: В. А. Маслова, Лингвокультурология, Москва: РАН. <https:// www.gumer.info/bibliotek_Buks/Linguist/maslova/index.php> 10. 3. 2020.

Шуригина 2014: Е. Н. Шурыгина, Понятие «картина мира» в лингвокультурологическом освещении, Ярославский педагогический вестник, № 6, <file:///c:/users/pc2012/downloads/ponyatie-kartina-mira-vlingvokulturologicheskom-osveshenii.pdf $>13$. 8. 2020.

Tanja Milosavljević

THE DIALECTICAL IMAGE OF THE WORLD AS A LINGUACULTURAL PHENOMENON

Summary

Contemporary Slavic dialectology is focused on shedding light on the phenomenon of the dialectical image of the world as a territorially limited segment of the national linguistic image of the world. Current research in this field of language study, especially in Russian studies, is the source of significant results for the reconstruction of the model of conceptualization and categorization of objective reality in the consciousness of the bearers of national speech and their linguistic interpretation and representation. The combination of modern theories and methodological mechanisms, primarily linguocognitive, anthropocentric, linguocultural has proven itself to be an adequate procedure in the analysis of dialectical material. Dialectical lexis is viewed as an adequate reflection of the world view and the mentality of the dialectical linguistic persona, and dialectical dictionaries have become the most relevant sources of study of linguacultural specificities of a specific speech community. A linguocultural approach to the dialectical lexical system enables the extraction of cultural components contained in the semantic content of the linguistic units in which we find accumulated information on the way of thinking, life and traditional culture of a community. The paper presents the realizations of certain axiological and cultural concepts in the linguistic knowledge of the bearers of the Serbian folk speeches and their manifestation in the Serbian dialectical (Prizren-Timok) linguistic image of the world.

Key words. Dialectal linguaculture, Prizren-Timok speeches, the concept of (un)hygienic. 